\title{
APSA 94th Annual Meeting \& Exhibition Hotel Information \& Reservation Form
}

\section{HOTEL RESERVATION FORM}

Arrival Date:

Departure Date:

Name (please print or type)

Street Address

\begin{tabular}{|c|c|c|}
\hline City & State & ZIP \\
\hline Daytime Phone & & \\
\hline
\end{tabular}

E-Mail

Check One: $\square$ Smoking $\square$ Non-smoking room requested Indicate 1st, 2nd, 3rd, 4th, 5th Hotel Choice \& Type of Accommodations Hotel Choices: Type of Room (Check One):

3.

4.

5

Names of All Occupants:

\section{ROOM DEPOSIT INFORMATION}

All hotels require a deposit of $\$ 100$ with each reservation request. The deposit amount is payable by credit card or check and will be applied to your hotel folio when you check in. Any cancellations without penalties must be made prior to August 7, 1998. After August 7, 1998 the hotel holding your reservation will provide your refund minus a $\$ 15.50$ processing fee. No refunds will be given within seven days of your arrival date. Rates are room per night and are subject to a $12.45 \%$ tax. Please complete the credit card information requested below, or enclose a check made out to the APSA Housing Bureau with your housing form. Reservation requests received without a deposit will be returned. If reservations are made by telephone, a credit card deposit must be provided.
$\square$ American Express
$\square$ VISA
$\square$ MasterCard

Credit Card Number

Exp. Date

Name on Card

\section{Signature}

Keep a copy of this form. Use one form per room required. Make additional copies if needed.

Do not send hotel reservation form to the Association. Send all hotel reservation forms to the APSA Housing Bureau. The Housing Bureau will send an official room confirmation. If you do not receive a confirmation by fax or mail within

14 days, please contact the APSA Housing Bureau.

A deposit is required in order to make a reservation.

To make your hotel reservations

beginning March 4, 1998, please do one of the following:

Call the APSA Housing Bureau

Monday through Friday

9:00 a.m. - 8:00 p.m. EST

1-800-399-2282 US \& Canada

617-923-8088

Boston Metro Area

and International

or Fax the hotel

reservation form to the APSA

Housing Bureau at 617-923-7737

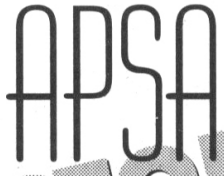

or Mail the hotel reservation

form to: APSA Housing Bureau

51 Water Street

Watertown, MA 02172

Reservations must

be received by the

Housing Bureau by

Friday, August 7, 1998.

\section{HOTELS \& RATES}

You must be a current member of APSA in order to qualify for member rates. *Rates at time of publication

\section{HEADQUARTER HOTEL}

\section{A Boston Marriott} Copley Place

110 Huntington Avenue

Member rates:

\$93 Single, \$116 Double

Nonmember:

\$289 Single/Double*

\section{HEADQUARTER HOTEL}

Sheraton Boston

B. Hotel \& Towers

39 Dalton Street

Member Rates:

\$93 Single/\$116 Double

Nonmember Rate:

\$259 Single/Double*
C Boston Park Plaza Hotel 64 Arlington Street Member Rates: \$105 Single/\$125 Double Nonmember Rates: \$235 Single/\$255 Double*

D The Westin Copley Place 10 Huntington Avenue Member Rates: \$109 Single/\$130 Double Nonmember Rate: \$290 Single/Double*

Е.

The Colonnade Boston

120 Huntington Avenue Member Rates: \$104 Single/\$127 Double Nonmember Rate: \$300 Single/Double* 


\section{Annual Meeting Discounts}

Airline Discounts

American Airlines, US Airways and Conventions in America have teamed up to offer discounted airfares to attendees of the $94^{\text {th }}$ APSA Annual Meeting. Both airlines are offering $5 \%$ off any published fare, or $10 \%$ off unrestricted fares with 7 day advance purchase on travel

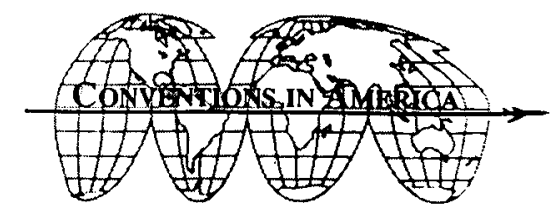
to Boston, MA. Take an additional $5 \%$ off if purchased 60 days prior to departure. All rules apply. Conventions in America will also offer lowest available fares on all other airlines, plus free flight insurance of $\$ 100,000$.

Call Conventions in America (CIA) at 800-929-4242 and ask for Group \#593

Outside U.S. \& Canada, call 619-453-3686 or fax 619-453-7976

Reservation hours: Monday through Friday, 6:30 a.m. to 5:00 p.m.

Pacific Time

Visit the CIA web site at http://www.scitravel.com

If you call the airlines directly, refer to the following codes:

American Airlines- 800-433-1790, Starfile \#4788UC

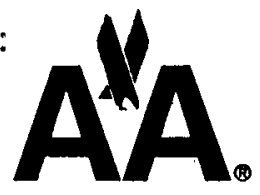

\section{吾 U.S AIRWAYS - 800-334-8644, Goldfile \#33140509}

\section{\& Car Rental Discounts}

APSA has negotiated special meeting rates with The Hertz Corporation for rental cars during the Annual Meeting, and including the week before and the week after the meeting. Special discounts range from a daily Compact rate of $\$ 41.99$ ( $\$ 37.99$ weekend) to a weekly Compact rate of $\$ 193.99$. Hertz is also offering discount rates on midsize, fullsize and luxury vehicles. The rates are subject to car availability and include free unlimited mileage. For reservations, call Hertz at 800-6542240 and refer to $\mathrm{CV} \# 40624$. 


\section{REGISTER NOW AND SAVE! \\ 94th APSA Annual Meeting \\ September 3-6, 1998 \\ Boston, MA}

Register now and save more than $30 \%$ off the on-site registration rates for the 1998 Annual Meeting! The program theme is Community, Communities, and Politics and over 700 panels and roundtables concerning all aspects of political science will be held at the Boston Marriott Copley Place, the Sheraton Boston Hotel and Towers and the Boston Park Plaza.

\section{REGISTRATION DEADLINE}

The APSA Council has adopted new preregistration guidelines. All non-exempt participants taking part in a panel, roundtable or poster session must preregister by Friday, March 13, 1998 or be omitted from the Preliminary Program. Friday, August 14, 1998 is the final preregistration deadline if you are attending panels, exhibits, professional placement service, or the panel paper room. Preregistration payments are not refundable.

Preregistration forms received at APSA after the August 14 deadline will not be processed, and attendees will be required to register on-site at the higher rates, so register today!

\section{EASY WAYS TO PREREGISTER}

1. Mail the following form with a check, VISA or MasterCard number and expiration date to:

American Political Science Association, Annual Meeting, P.O. Box 631130,

Baltimore, MD 21263-1130.

2. Fax the following form with a VISA or MasterCard number and expiration date to 202-483-2657.

$O R$

3. Send an e-mail to meeting@apsanet.org. Please include all of the information listed below including a VISA or MasterCard number and expiration date.

$O R$

4. Visit the APSA Web Site at http://www.apsanet.org and complete the preregistration form including a VISA or MasterCard number and expiration date.

A preregistration confirmation/receipt will be mailed to you within two weeks of receiving payment. Receipts can not be mailed or faxed after the Annual Meeting. Please do not submit your preregistration form and payment more than one way or you will be double charged.

\section{PREREGISTRATION FORM}

(Please type or print)

APSA Member Type (circle one): Your membership must be current in order to qualify for member rates.
Regular, Associate, Family, Retired, or Unemployed Member
$\$ 75.00$
Student Member (applies only to student members of APSA)
$\$ 25.00$
Non Member
$\$ 130.00$

If you are not an APSA member, we encourage you to become one so that you can take advantage of lower registration fees, hotel rates and travel discounts. Call APSA at 202-483-2512 or e-mail

membership@apsanet.org.

Name:

Address:

Telephone \#:(w)

(h)

E-mail: Fax \#:

Institutional Affiliation (for badge):

Amount of Payment: \$

Check (payable to APSA) MasterCard

Account \# $-$

Exp. Date: 1

Signature: 


\section{Professional Placement Service 1998 Annual Meeting}

APSA will sponsor its annual Professional Placement Service at the Sheraton Boston Hotel and Towers, during the 1998 Annual Meeting in Boston, Massachusetts. The Placement Service will be open from 8:00 a.m. to 6:00 p.m., Thursday, September 3 through Saturday, September 5; and from 9:00 a.m. to 11:00 a.m., Sunday, September 6. Facilities will be available to review job listings and resumes, exchange messages, and conduct interviews. All persons using the Professional Placement Service are required to register for the 1998 Annual Meeting. Badges must be worn for admittance to the Professional Placement Service.

Employers who are not members of the APSA Departmental Services Program will be charged a Service 'Fee of $\$ 100.00$ (Prepaid). CANDIDATES WHO DO NOT PREREGISTER FOR THE MEETING WILL BE CHARGED \$10.00 TO REGISTER AT THE MEETING.

Forms for Preregistering with the Placement Service, may be obtained by any of the following methods:

1) Completing the Candidate or Employer form available on the APSA web site at www.apsanet.org. Electronic resumes should be submitted along with the Candidate Form and should not exceed three printed pages. Submission Deadline: August 7, 1998.

2) E-mailing your request to psn@apsanet.org, not later than July 10, 1998. Employer and/or Candidate Forms will be forwarded to you upon receipt of your request.

3.) Looking for copies of the Candidate form in the June 1998 issue of PS: Political Science and Politics. Complete and return the form to the National Office by no later than August 7, 1998 


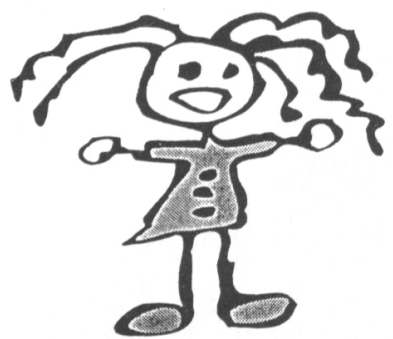

\author{
CHILD CARE SERVICE \\ 94TH APSA Annual Meeting \\ Boston, MA \\ September 3-6, 1998
}

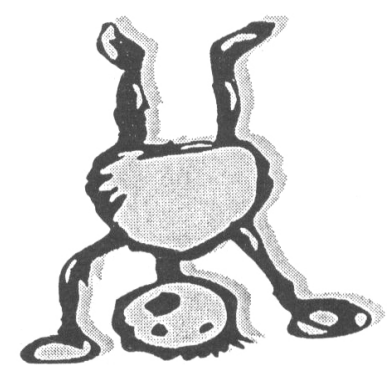

The American Political Science Association will sponsor a Child Care Service at the 94th Annual Meeting in Boston, MA. Child care will be available daily in the Boston Marriot Copley Place from Thursday, September 3 through Sunday, September 6. The hours of operation are from 8:30 am to 10:30 pm except on Sunday, September 6 when the hours of operation will be from 8:30 am to $12: 30 \mathrm{pm}$.

KiddieCorp child care is available for unlimited use to children of registrants at the 1998 Annual Meeting. Parents will be asked to complete a tentative schedule following confirmation of their child care service registration. Nutritious snacks and beverages will be provided. Breakfast, lunch and dinner must be provided by the parents. Diapers, special milk or formula, as well as any written special feeding instructions should be supplied by the parents.

To participate in the child care service, follow these instructions:

1. Complete the child care registration form below and submit it to APSA by July 15 , 1998.

2. A $\$ 50.00$ fee is required for each registered child if you are a professional, associate, family, retired or unemployed member. $A \$ 35.00$ fee is required for each registered child if you are a graduate student member. Payment must be made with the submission of the child care registration form.

3. All registration forms and payments must be received at APSA by July 15, 1998. There will be limited on-site registration. On-site registration will require a $\$ 65.00$ fee per child if you are a professional, associate, family, retired or unemployed member. The on-site registration fee for graduate student members is $\$ 50.00$ per child. APSA does not guarantee space for children registered on-site.

KiddieCorp staffing will be provided according to the following staff to child ratios:

$1: 2$ ratio for children 6 months * to 1 year old

$1: 3$ ratio for children 1 to 3 years old

$1: 5$ ratio for children over 3 years old

*Please Note: Minimum age for the child care service is 6 months.

แ+เ

\title{
CHILD CARE REGISTRATION FORM
}

Name of Parent:

Home Address:

Daytime Phone \#:

List child/children:

Name:

Age:

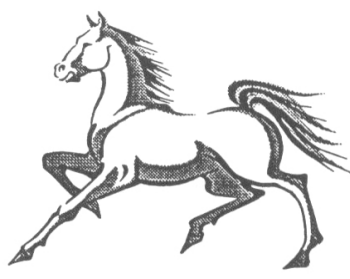

Mail to:

Name:

Age:

Child Care Coordinator APSA

1527 New Hampshire Ave, NW

Name:

Age: 


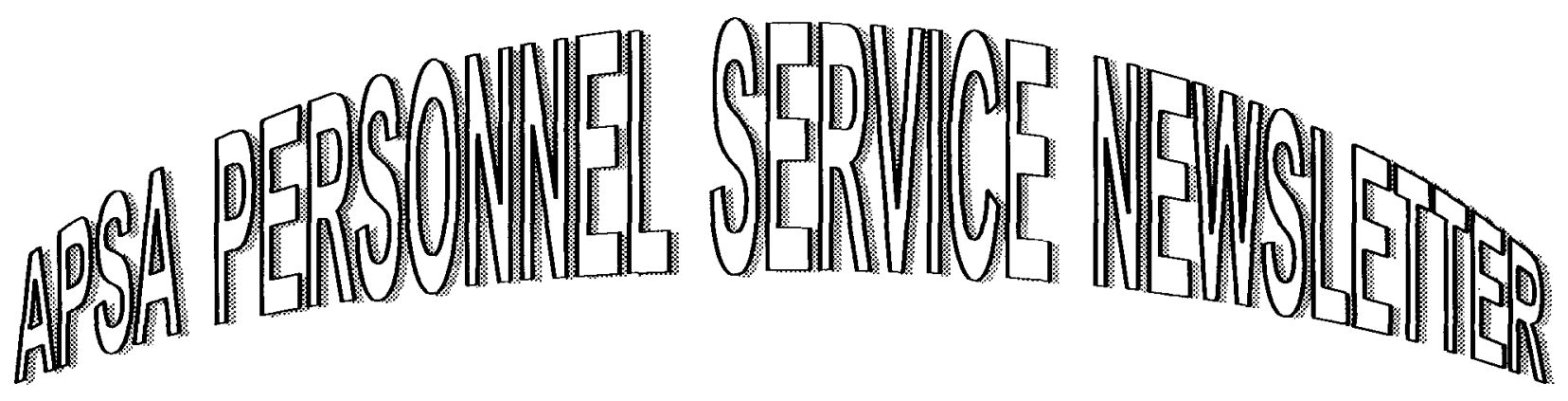

\section{THE MOST COMPREHENSIVE LISTINGS OF POSITIONS IN POLITICAL SCIENCE}

For political science positions in Administrative, Teaching, Non-Academic, and Research areas, you need to subscribe to the APSA Personnel Service Newsletter. In addition to teaching and research positions, the Newsletter lists up-to-date information on Fellowship and Grant opportunities for political scientists, and Faculty Exchange information. Take advantage of this opportunity to advance your career in teaching and research.

Your APSA MEMBERSHIP qualifies you to become a subscriber to the Newsletter. The subscription rate is $\$ 35.00$ annually. (Foreign subscriptions add $\$ 25.00$ for postage). Complete the form below and begin receiving your personal copy immediately. Mail TO: American Political Science Association/Membership, P.O. Box 631125, Baltimore, MD 21263-1125.

NAME:

ADDRESS:

CITY: STATE: ZIP:

\$35.00 Personnel Service Newsletter $\square \$ 25.00$ Overseas Air Mail Postage $\square$ Check (Drawn on U.S. Bank) $\square$ Master Card $\square$ Visa

Card No: $-$ $-$ $-$ Exp. Date:

Signature: 